\title{
MEDIASI SEBAGAI PENYELESAIAN PERMASALAHAN TENAGA KERJA DI KABUPATEN BANGKALAN
}

\author{
Abd Latip, Lu'luiaily, Ainiyah \\ Universitas Trunojoyo Madura
}

\begin{abstract}
The relationship between workers and employers does not always run smoothly, there are times when one or both parties neglect their obligations or do not fulfill their rights. With the non-fulfillment of these rights or obligations, it can lead to industrial relations disputes between workers and employers. Appropriate disputes can be resolved between each party through Bipartite which is carried out by the Bangkalan City Manpower Office based on deliberation and consensus and will result in a joint agreement between the two parties. But often with this agreement no agreement was reached, so that the dispute issue was resolved in a tripartite manner through mediation, conciliation, arbitration. The problem in this article is how the implementing regulations are in resolving industrial relations disputes and what are the driving and inhibiting factors in the effectiveness of work relations in resolving industrial relations disputes.
\end{abstract}

Keywords : Industrial relations, effectiveness, Mediation, and industrial relations regulations.

\section{PENDAHULUAN}

Hubungan Industrial pada dasarnya adalah suatu hubungan hukum yang dilakukan antara pengusaha dengan pekerja. Dalam hubungan tersebut memang tidak selamanya akan berjalalan lancar-lancar saja dalam arti tidak ada permasalahan yang timbul dari hubungan industrial. Ini terbukti dengan banyaknya pemberitaan di media massa saat ini yang memberitakan perselisihan-perselisihan di dalam hubungan industrial tersebut. Banyak faktor yang menjadi penyebab dalam permasalahan atau perselisihan hubungan industrial antara pekerja dan pengusaha, yang antara lain adalah Pemutusan Hubungan Kerja atau PHK atau karena tidak adanya pemenuhan hak-hak bagi pekerja. Namun, tidak hanya itu, permasalahan hubungan industrial juga bisa terjadi anatara para pekerja sendiri. Misalkan antara serikat pekerja dalam satu perusahaan. Karena banyak perselisihan-perselisihan yang timbul dalam hubungan industrial tersebut, maka perlu di cari cara terbaik dalam menyelesaikan permasalah atau perselisihan hubungan industrial antara pekerja dengan pengusaha atau pekerja dengan pekerja. Lalu yang menjadi pertanyaan adalah bagaimana menyelesaikan masalah tersebut, hal ini perlu dikaji secara jelas sehingga dalam hubungan 
industrial antara pekerja dengan pengusaha tercipta sebuah hubungan yang harmonis dalam upaya mewujudkan suasana ketenagakerjaan yang baik dan harmonis di negeri ini.

Menurut Undang-Undang No. 2 Tahun 2004 tentang Penyelesaian Perselisihan Hubungan Industrial bahwa yang dimaksud dengan perselisihan hubungan industrial adalah perbedaan pendapat yang mengakibatkan pertentangan antara pengusaha dengan buruh atau serikat pekerja karena adanya perselisihan mengenai hak, perselisihan kepentingan, perselisihan pemutusan hubungan kerja serta perselisihan antar serikat buruh dalam satu perusahaan. Berdasarkan pasal 2 UU PHI, jenis -jenis hubungan industrial meliputi:

1. Perselisihan hak

Perselisihan hak adalah perselisihan yang timbul karena tidak dipenuhinya hak. Akibat adanya perbedaan pelaksanaan atau penafsiran terhadap ketentuan peraturan perundang-undangan, perjanjian kerja, peraturan perusahaan atau perjanjian kerja bersama.

2. Perselisihan kepentingan

Perselihan kepentingan adalah perselisihan yang timbul dalam hubungan kerja karena tidak adanya kesesuaian pendapat mengenai pembuatan, dan/atau perubahan syarat-syarat kerja yang diterapkan didalam perjanjian kerja, atau peraturan perusahaan atau perturan kerja bersama.

3. Perselisihan pemutusan hubungan kerja

Perselisihan pemutusan hubungan kerja adalah perselisihan yang timbul karena tidak adanya kesesuaian pendapat mengenai pengakhiran hubungan kerja yang dilakukan salah satu pihak.

4. Perselisihan antar serikat pekerja/serikat buruh dalam satu perusahaan.

Perselisihan antar serikat pekerja /serikat buruh dalam satu perusahaan adalah perselisihan antara serikat pekerja /serikat buruh dengan serikat pekerja /serikat buruh lainya dalam satu perusahaan karena tidak adanya persesuaian paham mengenai keanggotaan, pelaksanaan hak dan kewajiban keserikatan pekerjaan.

Macam-macam perselisihan tersebut acap kali timbul dalam suatu perusahaan sehingga butuh suatu wadah hukum untuk menyelesaikan perselisihan-perselisihan tersebut. Pada Tahun 1957 sudah ada peraturan yang mengatur Penyelesaian Perselisihan Hubungan Industrial yang pada waktu itu disebut dengan perselisihan perburuhan yaitu 
Undang-undang No.22 Tahun 1957. Dalam Pasal 1 ayat (1) huruf c Undang-Undang No. 22 Tahun 1957 tentang Penyelesaian Perselisihan Perburuhan yang dimaksud Perselisihan Perburuhan adalah "pertentangan antara majikan atau perkumpulan majikan dengan serikat buruh atau gabungan serikat buruh berhubung dengan tidak adanya persesuaian paham mengenai hubungan kerja, syarat-syarat kerja dan/atau keadaan perburuhan". Karena undang-undang ini telah sangat lama, makin banyaknya macam-macam perselisihan yang ada pada saat ini dan karena proses penyelesaian perselisihan yang dalam menyelesaikannya sangat lama maka lahirlah Undang- Undang No. 2 tahun 2004 diatas. Dengan lahirnya undang-undang No.2 tahun 2004 maka proses dalam menyelesaikan sengketa antara pengusaha dan tenaga kerja lebih mudah dan cepat diselesaikan.

Undang-undang No. 2 tahun 2004 mengatur cara - cara untuk menyelesaikan perselisihan hubungan industrial, sebelum mengajukan sengketa ke pengadilan hubungan industrial terdapat langkah-langkah yang harus dilakukan pihak yang bersengketa yaitu menyelesaikan perkara secara bipartite dan jika cara ini tidak berhasil Kementerian Tenaga Kerja dan Transmigrasi atau instansi yang berwenang di bidang ketenagakerjaan setempat akan menawarkan penyelesaian melalui:

1. Arbitrase: penyelesaian suatu perselisihan kepentingan, dan perselisihan antar serikat pekerja dalam satu perusahaan. Ini dilakukan di luar Pengadilan Hubungan Industrial melalui kesepakatan tertulis dari para pihak yang berselisih untuk menyerahkan penyelesaian perselisihan kepada arbiter yang putusannya mengikat para pihak dan bersifat final.

2. Konsiliasi: penyelesaian perselisihan kepentingan, perselisihan pemutusan hubungan kerja atau perselisihan antar serikat pekerja hanya dalam satu perusahaan. Ini dilakukan melalui musyawarah yang ditengahi oleh seorang atau lebih konsiliator yang netral.

Jika tidak satu pun opsi di atas dipilih oleh para pihak dalam waktu 30 hari, perselisihan tersebut akan diselesaikan melalui proses mediasi, "mediasi hubungan industrial yang selanjutnya disebut mediasi adalah penyelesaian perselisihan hak, perselisihan kepentingan, perselisahan pemutusan hubungan kerja, dan perselisihan antar serikat pekerja / serikat buruh dalam satu perusahaan melalui musyawarah yang ditengahi oleh seorang atau lebih mediator yang netral”. Jika dalam mediasi pun tidak ditemukan perdamaian atau jalan keluar masalah, maka sengketa tersebut dapat diajukan 
terhadap pemerintah provinsi melalui dinas wilayah provinsi. Mediasi merupakan salah satu cara penyelesaian yang mudah, hemat waktu dan biaya, mediasi adalah penyelesaian sengketa yang lengkap ia dapat menyelesaikan ke empat macam perselisihan, beda halnya dengan arbitrase maupun konsiliasi yang tidak dapat menyelesaikan semua macam perselisihan hubungan industrial. menurut undang-undang No.2 tahun 2004 pasal 8, penyelesaian perselisihan melalui mediasi dilakukan oleh mediator yang berada di setiap kantor instansi yang bertanggung jawab dibidang ketenaga kerjaan kabupaten/kota. Dengan semua kelebihan tersebut seharusnya mediasi menjadi sarana yang ampuh dalam menyelesaikan sengketa perburuhan.

Upaya mediasi sering dilakukan disnaker Kabupaten bangkalan dalam menyelesaikan masalah perburuhan di Bangkalan yang mana wajib dilakukan oleh pihak yang bersengketa sebelum kasus dilimpahkan ke pengadilan dan mediasi ini cukup berhasil dengan banyaknya kasus yang terselesaikan dan berakhir damai, apabila kesepakatan tercipta maka salah satu pihak mempunyai hak eksekusi atas pihak lainya dan pihak lainya mempunyai kewajiban untuk memenuhi hasil dari mediasi, tapi terkadang terdapat sengketa yang tidak dapat diselesaikan dengan mediasi atau berlarut-larut tanpa menemukan kejelasan yang tentunya merugikan para buruh, walaupun ketika itu terjadi, buruh/pengusaha masih memiliki hak dan upaya untuk menyelesaikan permasalahn di pengadilan. Dengan diamanatkanya proses penyelesaian sengketa perburuhan oleh undangundang kepada dinas tenaga kerja Bangkalan melalui jalur mediasi dengan biaya ringan, cepat, transparan dan berazas netral, seharusnya segala macam perselisihan dapat diselesaikan dengan damai atau kekeluargaan dan tidak sampai kepihak pengadilan karena penyelesaian melalui pengadilan akan membutuhkan waktu yang sangat lama apalagi jika mereka melakukan kasasi yang akan membuat para buruh dirugikan dengan lamamanya waktu tersebut. dan keputusannya yang akan merugikan salah satu pihak, akan tetapi proses mediasi oleh disnaker tidak selamanya dapat berjalan lancar atau dapat diselesaikan dengan mediasi seperti yang telah saya sebutkan diatas.

Pada data dinas tenaga kerja Bangkalan bulan September 2018 jumlah perselisihan perburuhan yang masuk ke dinas tenaga kerja bangkalan seringkali ialah pemutusan hubungan kerja dengan cara sepihak dan pemberian upah tidak susuai dengan UMK dengan ini dinas tenaga kerja Bangkalan selalu menampung permasalahan yang dating dan seringkali dilakukan penyelesaian dengan cara mediasi. Dengan lahirnya undang-undang 
No.2 tahun 2004 yang mengatur penyelesaian perselisihan industrial ini melalui mediasi dengan segala manfaat dan segala kelebihanya dalam meyelesaikan sengketa industrial seharusnya dapat menyelesaikan perselisihan perburuhan dengan mekanisme Penyelesaian Perselisihan Hubungan Industrial yang sederhana, cepat, adil dan murah yang juga dilihat dari aspek hukum acara perdata demi untuk menjamin kepastian hukum para buruh.

\section{TINJAUAN PUSTAKA}

\section{Pengertian Mediasi}

Secara etimologi, istilah mediasi berasal dari bahasa latin, mediare yang berarti berada di tengah. Makna ini menunjukkan pada peran yang ditampilkan pihak ketiga sebagai mediator dalam menjalankan tugasnya menengahi dan menyelesaikan sengketa antara para pihak. 'Berada di tengah' juga bermakna mediator harus berada pada posisi netral dan tidak memihak dalam menyelesaikan sengketa. Mediator harus mamapu menjaga kepentingan para pihak yang bersengketa secara adil dan sama, sehingga menumbuhkan kepercayaan (trust) dari para pihak yang bersengketa. Penjelasan mediasi dari sisi kebahasaan (etimologi) lebih menekankan pada keberadaan pihak ketiga yang menjembatani para pihak bersengketa untuk menyelesaikan perselisihannya. Mediator berada pada posisi di tengah dan netral antara para pihak yang bersengketa, dan mengupayakan menemukan sejumlah kesepakatan sehingga mencapai hasil yang memuaskan para pihak yang bersengketa. Dalam Kamus Besar Bahasa Indonesia, kata mediasi diberi arti sebagai proses pengikutsertaan pihak ketiga dalam penyelesaian suatu perselisihan sebagai penasihat. Pengertian yang diberikan Kamus Besar Bahasa Indonesia mengandung tiga unsur penting. Pertama, mediasi merupakan proses penyelesaian perselisihan atau sengketa yang terjadi antara dua pihak atau lebih. Kedua, pihak yang terlibat dalam penyelesaian sengketa adalah pihak-pihak yang berasal dari luar pihak yang bersengketa. Ketiga, pihak yang terlibat dalam penyelesaian sengketa tersebut bertindak sebagai penasihat dan tidak memiliki kewenangan apa-apa dalam pengambilan keputusan.

Pengertian mediasi secara terminologi dapat dilihat dalam Peraturan Mahkamah Agung Nomor 01 Tahun 2008 tentang Prosedur Mediasi di Pengadilan, mediasi adalah cara penyelesaian sengketa melalui proses perundingan untuk memperoleh kesepakatan para pihak dengan dibantu oleh mediator. Mediator adalah pihak netral yang membantu 
para pihak dalam proses perundingan guna mencari berbagai kemungkinan penyelesaian sengketa tanpa menggunakan cara memutus dan memaksakan sebuah penyelesaian. Tetapi, banyak para ahli juga mengungkapkan pengertian mediasi di antaranya Prof. Takdir Rahmadi yang mengatakan bahwa mediasi adalah suatu proses penyelesaian sengketa antara dua pihak atau lebih melalui perundingan atau cara mufakat dengan bantuan pihak netral yang tidak memiliki kewenangan memutus. Pihak mediator tersebut disebut mediator dengan tugas memberikan bantuan prosedural dan substansial.

Dengan demikian, dari definisi atau pengertian mediasi ini dapat diidentifikasikan unsurunsur esensial mediasi, yaitu :

1. Mediasi merupakan cara penyelesaian sengketa melalui perundingan berdasarkan pendekatan mufakat atau konsensus para pihak;

2. Para pihak meminta bantuan pihak lain yang bersifat tidak memihak yaitu mediator;

3. Mediator tidak memilikikewenangan memutus, tetapi hanya membantu para pihak yang bersengketa dalam mencari penyelesaian yang dapat diterima para pihak.

\section{Tujuan dan Manfaat Mediasi}

Mediasi merupakan salah satu bentuk dari alternatif penyelesaian sengketa di luar pengadilan. Tujuan dilakukan mediasi adalah menyelesaikan sengketa antara para pihak dengan melibatkan pihak ketiga yang netral dan imparsial. Mediasi dapat mengantarkan para pihak pada perwujudan kesepakatan damai yang permanen dan lestari, mengingat penyelesaian sengketa melalui mediasi menempatkan kedua belah pihak pada posisi yang sama, tidak ada pihak yang dimenangkan atau pihak yang dikalahkan (win-win solution). Dalam mediasi para pihak yang bersengketa pro aktif dan memiliki kewenangan penuh dalam pengambilan keputusan. Mediator tidak memiliki kewenangan dalam pengambilan keputusan, tetapi ia hanya membantu para pihak dalam menjaga proses mediasi guna mewujudkan kesepakatan damai mereka. Penyelesaian sengketa melalui jalur mediasi sangat dirasakan manfaatnya, karena para pihak telah mencapai kesepakatan yang mengakhiri persengketaan mereka secara adil dan saling menguntungkan. Bahkan dalam mediasi yang gagal pun, dimana para pihak belum mencapai kesepakatan, sebenarnya juga telah dirasakan manfaatnya. Kesediaan para pihak bertemu dalam suatu proses mediasi, paling tidak telah mampu mengklarifikasikan akar persengketaan dan mempersempit perselisihan di antara mereka. Hal ini menunjukkan adanya keinginan para pihak untuk 
menyelesaikan sengketa, namun mereka belum menemukan format tepat yang dapat disepakati oleh kedua belah pihak.

Penyelesaian sengketa memang sulit dilakukan, namun bukan berarti tidak mungkin diwujudkan dalam kenyataan. Modal utama penyelesaian sengketa adalah keinginan dan i'tikad baik para pihak dalam mengakhiri persengketaan mereka. Keinginan dan i'tikad baik ini, kadang-kadang memerlukan bantuan pihak ketiga dalam perwujudannya. Mediasi merupakan salah satu bentuk penyelesaian sengketa yang melibatkan pihak ketiga. Mediasi dapat memberikan sejumlah keuntungan antara lain:

1. Mediasi diharapkan dapat menyelesaikan sengketa secara cepat dan relatif murah dibandingkan dengan membawa perselisihan tersebut ke pengadilan atau ke lembaga arbitrase.

2. Mediasi akan memfokuskan perhatian para pihak pada kepentingan mereka secara nyata dan pada kebutuhan emosi atau psikologis mereka, sehingga mediasi bukan hanya tertuju pada hakhak hukumnya.

3. Mediasi memberikan kesempatan para pihak untuk berpartisipasi secara langsung dan secara informal dalam menyelesaikan perselisihan mereka.

4. Mediasi memberikan para pihak kemampuan untuk melakukan kontrol terhadap proses dan hasilnya.

5. Mediasi dapat mengubah hasil, yang dalam litigasi dan arbitrase sulit diprediksi, dengan suatu kepastian melalui suatu konsensus.

6. Mediasi memberikan hasil yang tahan uji dan akan mampu menciptakan saling pengertian yang lebih baik di antara para pihak yang bersengketa karena mereka sendiri yang memutuskannya.

7. Mediasi mampu menghilangkan konflik atau permusuhan yang hampir selalu mengiringi setiap putusan yang bersifat memaksa yang dijatuhkan oleh hakim di pengadilan atau arbiter pada lembaga arbitrase.

Dalam kaitan dengan keuntungan mediasi, para pihak dapat mempertanyakan pada diri mereka masing-masing apakah mereka dapat hidup dengan hasil yang dicapai melalui mediasi (meskipun mengecewakan atau lebih buruk daripada hal yang diharapkan). Bila direnungkan lebih dalam bahwa hasil kesepakatan yang diperoleh melalui jalur mediasi jauh lebih baik lagi, bila dibandingkan dengan para pihak terusmenerus berada dalam persengketaan yang tidak pernah selesai, meskipun persepakatan 
tersebut tidak seluruhnya mengakomodasikan keinginan para pihak. Pernyataan win-win solution pada mediasi, umumnya datang bukan dari istilah penyelesaian itu sendiri, tetapi dari kenyataan bahwa hasil penyelesaian memungkinkan kedua belah pihak meletakkan perselisihan di belakang mereka. Pertemuan secara terpisah dengan para pihak dapat lebih meyakinkan pihak yang lemah akan posisi mereka, sehingga mediator dapat berupaya mengatasinya melalui saran dan pendekatan yang dapat melancarkan proses penyelesaian sengketa. Proses mediasi dan keahlian mediator menjadi sangat penting dalam kaitannya dengan pencegahan dan penyalahgunaan kekuasaan.

\section{Unsur-Unsur Mediasi}

Berawal dari ketidakpuasan akan proses pengadilan yang memakan waktu relatif lama, biaya yang mahal, dan rasa ketidakpuasan pihak yang merasa sebagai pihak yang kalah, dikembangkan mediasi sebagai salah satu cara penyelesaian sengketa di luar pengadilan. Penerapan mediasi diberbagai negara secara umum mengandung unsurunsur:

1. Sebuah proses sengketa berdasarkan perundingan .

2. Adanya pihak ketiga yang bersifat netral yang disebut sebagai mediator (penengah) terlibat dan diterima oleh para pihak yang bersengketa di dalam perundingan itu.

3. Mediator tersebut bertugas membantu para pihak yang bersengketa untuk mencari penyelesaian atas masalah-masalah sengketa

4. Mediator tidak mempunyai kewenangan membuat putusan selama proses perundingan berlangsung.

Mempunyai tujuan untuk mencapai atau menghasilkan kesepakatan yang dapat diterima para pihak yang bersengketa guna mengakhiri sengketa.

\section{HASIL DAN PEMBAHASAN}

\section{Peraturan Hubungan Industrial}

Hubungan industrial adalah hubungan antara semua pihak yang tersangkut atau berkepentingan atas proses produksi atau pelayanan jasa di suatu perusahaan yang meliputi pengusaha, pekerja, pemerintah dan masyarakat (customer, supplier, lingkungan). Hubungan industrial tersebut harus dicipatkan sedemikian rupa agar aman, harmonis, serasi dan sejalan, agar perusahaan dapat terus meningkatkan produktivitasnya untuk 
meningkatkan kesejahteraan semua pihak yang terkait atau berkepentingan terhadap perusahaan tersebut. Peraturan undang-undang ketenagakerjaan merupakan bentuk campur tangan pemerintah dalam hubungan industrial yang bertujuan untuk menjamin hak - hak dasar pekerja/buruh dan meniamin kesamaan kesempatan serta perlakuan tanpa diskriminasi atas dasar apapun untuk mewujudkan kesejahteraan pekerja/buruh dan keluarganva dengan tetap memperhatikan perkembangan kemajuan dunia usaha. Peraturan perundang-undangan ketenagakerjaan biasa disebut dengan hukum ketenagakerjaan atau hukum perburuhan, secara pengertian para ahi metuberikan pengertian yang berbeda-beda, hal ini bergantung dari hukum positif yang berlaku berbeda di setiap negara. Pengertian peraturan undang - undangan ketenagakerjan/hokum perburuhan dari beberapa ahli :

1. EH van Asveld : Hukum Ketenagakerjaan adalah hukum yang bersangkutan dengan pekeriaan di dalam hubungan kerja dan di luar hubungan kerja.

2. Soetiksno : Hukum Ketenagakerjaan merupakan keseluruhan peraturan-peraturan hukum mengenai hubungan kerja yang mengakibatkan seorang secara pribadi ditempatkan di bawah pimpinan (perintah) orang lain dan keadaan - keadaan penghidupan yang langsung bersangkut paut dengan hubungan kerja tensebut.

3. Prof. Imam Soepomo : Hukum ketenagakerjaan sebagai hhimpunan dari peraturan - peratuuran, baik peraturan tertulis maupun tidak tertulis yang berkenaan dengan kejadian dimana seseorang bekerja pada orang lain dengan menerima upah.

4. Halim : hukum perburuhan adalah peraturan-peraturan hukum yang mengatur hubungan kerja yang harus diindahkan oleh semua pihak, baik pihak buruh pekerja maupun pihak majikan.

5. Daliyo : hukum perburuhan adalah himpunan peraturan, baik yang tertulis maupun yang tidak tertulis yang mengatur hubungan kerja antar buruh dan majikan dengan mendapat upah sebaqai balas jasa.

Dengan demikian ketenagakerjaan merupakan salah satu aspek penting dalam kegiatan ekonomi nasional. Karena itu, aspek ini harus mendapat perhatian penting, yang harus menjadi perhatian dalam upaya pembangunan ekonomi sebuah negara.Tujuan pembangunan ketenagakerjaan adalah melindungi hak warga negara dalam memperoleh pekerjaan, melindungi tenaga kerja dari resiko kerja dalam melakukan pekerjaan, melindungi tenaga kerja dari bentuk-bentuk perlakuan buruk, tidak layak, diskriminasi serta eksploitasi baik fisik, mental, moral maupun sosial, serta melindungi segenap hak- 
hak tenaga kerja yang timbul dari perikatan maupun peraturan perundang-undangan. Pembangunan ketenagakerjaan juga harus mengarah pada upaya mencerdaskan dan meningkatkan keahlian dan ketrampilan tenaga kerja agar dapat memenuhi tuntutan pasar kerja, meningkatkan posisi tawar, serta meningkatnya Penghasilan. Kemudian, menyejahterakan dan menjamin Pemenuhan kebutuhan tenaga kerja untuk hidup layak meliput. Tingkat penghasilan/pengupahan, kesejahteraan dan jaminan sosial bagi diri dan keluarganya.

Perlindungan terhadap hak-hak pekerja dilakukan dengan cara menyediakan upaya hukum kepada yang haknya telah dilanggar, agar dapat dipulihkan kembali dan atau dipenuhi. Hukum membedakan upaya hukum untuk melindungi hak seseorang dalam beberapa macam: upaya hukum perdata, upaya hukum pidana, upaya hukum administrasi, dan upaya hukum tata negara bahkan upaya hukum yang disediakan secara lintas negara. Dengan demikian, ada hukum yang bersifat privat dan ada juga upaya hukum publik. Perlindungan kepentingan dengan cara memberikan hak akan lebih kuat, apabila terhadap subyek yang kepadanya hak diberikan juga dilengkapi dengan upaya-upaya hukum untuk mempertahankan haknya. Artinya, hukum memberikan hak kepada entitas hukum untuk mengontrol pelaksanaan kewajiban oleh pihak lain memenuhi hak-hak pekerja. Upaya perlindungan hukum terhadap pekerja harus dilaksanakan secara maksimal. Hukum merupakan kehendak dan ciptaan manusia, berupa norma-norma yang berisikan petunjuk petunjuk tingkah laku, tentang apa yang boleh dilakukan dan tentang apa yang tidak boleh dilakukan. Oleh karena itu, hukum harus mempunyai sanksi dan mengandung nilai-nilai keadilan, kegunaan serta nilai kepastian dalam masyarakat tempat hukum diciptakan, untuk mewujudkan nilai-nilai keadilan, kegunaan serta nilai kepastian itu perlu ada upayaupaya hukum untuk mempertahankannya.

Terkait dengan upaya-upaya hukum melindungi pekerja, pemerintah pada dasarnya berwenang mengambil langkah-langkah sebagai berikut:

1. Melakukan intervensi dalam hubungan kelja guna meminimalisir perselisihan hubungan industrial

2. Mengawasi dan mengambil tindakan yang tegas terhadap segala bentuk eksploitasi pekerja; 
3. Mengawasi penerapan norma kerja dan norma k3 sehingga ada jaminan dari pengusaha untuk selalu memberikan perlindungan kerja dan syarat-syarat kerjabagipekerja;

4. Menciptakan ketentuan dalam hubungan kerja dengan memaksa pengusaha agar memenuhi ketentuan dan syarat-syarat kerja sebagaimana di atur dalam uu no. 13 tahun 2003 tentang ketenagakerjaan.

Perundangan hubungan industrial dibuat pada hakikatnya selain bertujuan untuk memberikan perlindungan hukum kepada pekerja/ buruh, juga untuk mewujudkan kesejahteraan bagi seluruhrakyat Indonesia, dalam hal ini untuk mewujudkan kesejahteraan pengusaha, kesejahteraan pekerja/buruh dan kesejahteraan masyarakat. Sasaran akhir dari sistem hukum hubungan industrial adalah membuka atau memperluas lapangan kerja, mempertahankan, meningkatkan keberlangsungan pekerjaan dan mempertahankan, meningkatkan pendapatan yang sudah ada, atau dalam jangka panjang bertujuan untuk meningkatkan pendapatan perkapita masyarakat Indonesia. Cara negara mewujudkan kesejahteraan rakyatnya, yaitu dengan menyusun dan melaksanakan program pembangunan nasional, termasuk negara menyusun dan melaksanakan program pembangunan di bidang ekonomi. Pengertian pembangunan ekonomi disini menurut Meier dan Baldwin dalam bukunya "Economics Development, Theory, History and Policy": "Pembangunan ekonomi adalah suatu proses di mana pendapatan nasional riil ekonomi meningkat dalam jangka waktu yang panjang. Dan jika laju perkembangan lebih besar dari laju pertumbuhan penduduk, maka pendapatan riil per kapita akan meningkat". Pembangunan ekonomi diartikan sebagai "suatu proses yang menyebabkan pendapatan perkapita penduduk suatu masyarakat meningkat dalam jangka panjang”. Pengertian pembangunan ekonomi tersebut mengandung tiga unsur :

1. Pembangunan ekonomi

2. Usaha meningkatkan pendapatan perkapita

3. Kenaikan pendapatan perkapita harus berlangsung dalam jangka panjang.

Tujuan akhir dari sistem hubungan industrial sangat mendukung terhadap pencapaian dari tujuan ekonomi nasional, tujuan sistem hubungan industrial adalah "kesejahteraan bagisemua pihak", yaitu untuk pihak pengusaha berupa peningkatan produktivitas dan bagi pekerja/buruh berupa peningkatan kesejahteraan, dan peningkatan ini harus dilakukan dari waktu kewaktu.Hal ini sejalan dengan pendapat dari beberapa 
sarjana tentang pengertian dari sistem hubungan industrial, seperti pengertian Hubungan Industrial dari Suprihanto yang menyatakan bahwa: "Hubungan yang membahas seluruh aspek dan permasalahan ekonomi, sosial, politik dan budaya baik yang secara langsung maupun tidak langsung yang berkaitan dengan hubungan pekerja, pengusaha dan pemerintah. Dalam UU No 13 Tahun 2003 memberikan pengertian terhadap peraturan perusahaan, perjanjian kerja bersama, dan perjanjian kerja. Peraturan perusahaan adalah peraturan yang dibuat secara tertulis oleh pengusaha yang memuat syarat-syarat kerja dan tata tertib dari perusahaan. Perjanjian kerja bersama adalah perjanjian yang merupakan hasil perundingan antara serikat pekerja/buruh atau beberapa serikat pekerja/buruh yang tercatat di instansi yang bertanggung jawab di bidang ketenagakerjaan dengan pengusaha atau beberapa pengusaha atau perkumpulan pengusaha yang memuat syarat-syarat kerja, hak dan kewajiban kedua belah pihak. Perjanjian kerja adalah perjanjian antara pekerja dengan pengusaha atau pemeberi kerja yang mempunya unsur pekerjaan upah dan perintah.

Dalam UU No 13 Tahun 2003, pengaturan lebih lanjut tentang tata cara pembuatan dan pengesahan peraturan perusahaan dan tata cara pembuatan perjanjian kerja sama telah diatur oleh Keputusan Menteri. Sebagai payung hukum di bidang ketenagakerjaan, diterbitkan UU No.13 Tahun 2003 tentang Ketenagakerjaan, yang memuat pokok-pokok sebagai berikut. Bab I, menjelaskan tentang pengertian berbagai hal yang menyangkut ketenagakerjaan, yaitu.

- Ketenagakerjaan adalah segala hal yang berhubungan dengan tenaga kerja pada waktu sebelum, selama, dan sesudah masa kerja.

- Tenaga kerja adalah setiap orang yang mampu melakukan pekerjaan guna menghasilkan barang dan/atau jasa baik untuk memenuhi kebutuhan sendiri maupun untuk masyarakat.

- Pekerja/buruh adalah setiap orang yang bekerja dengan menerima upah atau imbalan dalam bentuk lain.

- Pemberi kerja adalah orang perseorangan, pengusaha, badan hukum, atau badanbadan lainnya yang mempekerjakan tenaga kerja dengan membayar upah atau imbalan dalam bentuk lain.

- Hubungan kerja adalah hubungan antara pengusaha dengan pekerja/buruh berdasarkan perjanjian kerja, yang mempunyai unsur pekerjaan, upah, dan perintah 
- Hubungan industrial adalah suatu sistem hubungan yang terbentuk antara para pelaku dalam proses produksi barang dan/atau jasa yang terdiri dari unsur pengusaha, pekerja/ buruh, dan pemerintah yang didasarkan pada nilai-nilai Pancasila dan Undang-Undang Dasar Negara Republik Indonesia Tahun 1945.

- Serikat pekerja/serikat buruh adalah organisasi yang dibentuk dari, oleh, dan untuk pekerja/buruh baik di perusahaan maupun di luar perusahaan, yang bersifat bebas, terbuka, mandiri, demokratis, dan bertanggung jawab guna memperjuangkan, membela serta melindungi hak dan kepentingan pekerja/buruh serta meningkatkan kesejahteraan pekerja/buruh dan keluarganya.

- Perjanjian kerja bersama adalah perjanjian yang merupakan hasil perundingan antara serikat pekerja/serikat buruh atau beberapa serikat pekerja/serikat buruh yang tercatat pada instansi yang bertanggung jawab di bidang ketenagakerjaan dengan pengusaha, atau beberapa pengusaha atau perkumpulan pengusaha yang memuat syarat-syarat ketja, hak dan kewajiban kedua belah pihak.

- Perselisihan hubungan industrial adalah perbedaan pendapat yang mengakibatkan pertentangan antara pengusaha atau gabungan pengusaha dengan pekerja/buruh atau serikat pekerja/serikat buruh karena adanya perselisihan mengenai hak, perselisihan kepentingan, dan perselisihan pemutusan hubungan kerja serta perselisihan antar serikat pekerja/ serikat buruh hanya dalam satu perusahaan.

- Mogok kerja adalah tindakan pekerja/buruh yang direncanakan dan dilaksanakan secara bersama-sama dan/atau oleh serikat pekerja/serikat buruh untuk menghentikan atau memperlambat pekerjaan.

- Upah adalah hak pekerja/buruh yang diterima dan dinyatakan dalam bentuk uang sebagai imbalan dari pengusaha atau pemberi kerja kepada pekerja/buruh yang ditetapkan dan dibayarkan menurut suatu perjanjian kerja, kesepakatan, atau peraturan perundang-undangan, termasuk tunjangan bagi pekerja/buruh dan keluarganya atas suatu pekerjaan dan/atau jasa yang telah atau akan dilakukan.

Ada 9 (sembilan) permasalahan yang sering timbul dan memicu konflik didalam perusahaan antara pekerja dan pengusaha, kesembilan itu adalah :

1. Solidaritas terhadap sesama pekerja yang dinilai telah diperlakukan secara kurangadil oleh perusahaan.

2. Perbedaan persepsi tentang perundangan dan peraturan pemerintah. 
3. Menuntut kepala personalia yang dinilai bersikap keras terhadap pekerja/buruh danberpihak pada perusahaan dan diminta agar mundur.

4. Perubahan manajemen perusahaan yang dinilai tidak memperhatikan kepentingandan kesejahteraan pekerja.

5. Menuntut adanya transparansi perusahaan (terutama berkaitan dengan keuntunganperusahaan yang mungkin dapat menjadi bagian pekerja/buruh dalam bentuk upahyang lebih tinggi atau peningkatan kesejahteraan).

6. Pelaksanaan peraturan uang pesangon; perusahaan dianggap tidak terbuka tentangkeuntungan perusahaan.

7. Kecurigaan mengenai adanya penyalahgunaan dana Jamsostek.

8. Ketidaksabaran pekerja dalam menunggu hasil perundingan.

9. Tuntutan-tuntutan baru lainnya yang muncul seiring dengan meningkatnyapengetahuan pekerja tentang hak-hak mereka setelah SP-TP terbentuk di tempat kerja mereka.

Beberapa Kepmen dan Undang-undang yang dapat mendukung proses permasalahan dalam hubungan industrial, yaitu :

1. Undang- Undang No. 21 Tahun 2000 tentang Serikat Pekerja/Serikat Buruh.

2. Kepmenakertrans No.16/Men/2001, tentang tatacara pencatatan SP/SB.

3. Kepmenakertrans No.201/Men/2001, tentang keterwakilan dalam kelembagaan Hubungan Industrial.

4. Kepmenakertrans RI No.Kep-255/Men/2003, tanggal 9 Desember 2003 tentang tatacara pembentukan dan susunan keanggotaan lembaga kerjasama Bipartit.

5. Kepmenakertrans RI No.Kep-255/Men/2003, tanggal 8 April 2004 tentang tatacara pembuatan dan pengesahan peraturan perusahaan serta pembuatan dan pendaftaran perjanjian kerja bersama.

Setelah mengetahui permasalahan - permasalahan diatas, maka pentingnya suatu lembaga untuk membantu menyelesaikan permasalahan diatas, diantaranya :

1. Kerja Sama Bipartit

Lembaga Kerja sama Bipartit adalah suatu badan ditingkat usaha atau unit produksi yang dibentuk oleh pekerja dan pengusaha.Setiap pengusaha yang mempekerjakan 50 (lima puluh) orang pekerja atau lebih dapat membentuk Lembaga Kerja Sama 
(LKS) Bipartit dan anggota-anggota yang terdiri dari unsur pengusaha dan pekerja yang ditunjuk berdasarkan kesepakatan dan keahlian.LKS Bipartit bertugas dan berfungsi sebagai Forum komunikasi, konsultasi dan musyawarah dalam memecahkan permasalahan-permasalahan ketenagakerjaan pada perusahaan guna kepentingan pengusaha dan pekerja.

2. Lembaga Kerja Sama Tripartit

Lembaga kerjasama Tripartit merupakan LKS yang anggota - anggotanya terdiri dari unsur-unsur pemerintahan, organisasi pekerja dan organisasi pengusaha. Fungsi lembaga kerjasama Tripartit adalah sebagai FORUM Komunikasi, Konsultasi dengan tugas utama menyatukan konsepsi, sikap dan rencana dalam mengahadapi masalah-masalah ketenagakerjaan, baik berdimensi waktu saat sekarang yang telah timbul karena faktor-faktor yang tidak diduga maupun untuk mengatasi hal-hal yang akan datang.

3. Organisasi Pekerja atau Serikat Pekerja/Buruh

Organisasi pekerja adalah suatu organisasi yang didirikan secara sukarela dan demokratis dari, oleh dan untuk pekerja dan berbentuk Serikat Pekerja, Gabungan serikat Pekerja, Federasi, dan Non Federasi. Kehadiran Serikat Pekerja di perusahaan sangat penting dan strategis dalam pengembangan dan pelaksanaan Hubungan Industrial.

4. Organisasi Pengusaha

Setiap pengusaha berhak untuk membentuk dan menjadi anggota organisasi pengusaha yaitu Asosiasi Pengusaha Indonesia (APINDO) yang khusus menangani bidang ketenagakerjaan dalam rangka pelaksanaan hubungan Industrial. Hal tersebut tercermin dari visinya yaitu terciptanya iklim usaha yang baik bagi dunia usaha dan misinya adalah meningkatkan hubungan industrial yang harmonis terutama ditingkat perusahaan, merepresentasikan dunia usaha Indonesia di lembaga ketenagakerjaan, dan melindungi, membela dan memberdayakan seluruh pelaku usaha khususnya anggota. Untuk menjadi anggota APINDO perusahaan dapat mendaftar di Dewan Pengurus Kota/Kabupaten (DPK) atau di Dewan Pengurus Provinsi (DPP) atau di Dewan Pengurus Nasional (DPN).

5. Peraturan Perusahaan 
Peraturan Perusahaan adalah suatu peraturan yang dibuat secara tertulis yang memuat ketentuan-ketentuan tentang syarat-syarat kerja serta tata tertib perusahaan.

6. Perjanjian Kerja Bersama

Perjanjian Kerja Bersama (PKB) adalah perjanjian yang disusun oleh pengusaha dan serikat yang telah terdaftar yang dilaksanakan secara musyawarah untuk mencapai mufakat.Perjanjian kerja Bersama ini dibuat atas persetujuan pemberi kerja dan Karyawan yang bersifat individual. Pengaturan persyaratan kerja yang bersifat kolektif dapat dalam bentuk Peraturan Perusahaan (PP) atau Perjanjian Kerja Bersama (PKB). Perjanjian Kerja Bersama atau PKB sebelumnya dikenal juga dengan istilah KKB (Kesepakatan Kerja Bersama) / CLA (Collective Labour Agreement) adalah perjanjian yang berisikan sekumpulan syarat-syarat kerja, hak dan kewajiban para pihak yang merupakan hasil perundingan antara Pengusaha, dalam hal ini diwakili oleh Managemen Perusahaan dan Karyawan yang dalam hal ini diwakili oleh Serikat Karyawan, serta tercatat pada instansi yang bertanggung jawab dibidang ketenagakerjaan.

\section{Penyelesaian Perselisihan Hubungan Industrial}

Penyelesaian konflik dapat dilakukan dengan cara-cara yang telah dibahas di atas, yaitu tentang ruang lingkup lembaga penanganan masalah hubungan industrial :

1. Perundingan Bipartit

Perundingan Bipartit adalah forum perundingan antar pengusaha dan karyawan atau serikatpekerja. Kedua belah pihak diharapkan dapat mencapai kesepakatan dalam penyelesaian masalah mereka, sebagai langkah awal dalam penyelesaian perselisihan. Dalam perundingan ini, harus dibuat risalah yang ditandatangai para pihak. Isi risalah diatur dalam Pasal 6 Ayat 2 UU PPHI. Apabila tercapai kesepakatan maka Para pihak membuat Perjanjian Bersama yang mereka tandatangani. Kemudian Perjanjian Bersama ini didaftarkan pada PHI wilayah oleh para pihak ditempat Perjanjian Bersama dilakukan.

2. Perundingan Tripartit

Mediasi, dinas tenaga kerja kemudian menunjuk mediator yang akan berusaha mendamaikan para pihak, agar tercipta kesepakatan antar keduanya. Dalam hal tercipta kesepakatan para pihak membuta perjanjian bersama dengan disaksikan oleh 
mediator. Bila tidak dicapai kesepakatan, mediator akan mengeluarkan anjuran. Penyelesaian melalui konsiliasi (conciliation) ini dilakukan melalui seorang atau beberapa orang atau badan sebagai penengah yang disebut konsiliator dengan mempertemukan atau memberi fasilitas kepada pihakpihak yang berselisih untuk menyelesaikan perselisihannya secara damai. Konsiliator ikut serta secara aktif memberikan solusi terhadap masalah yang diperselisihka. Arbitrase lain dengan produk Mediasi dan Konsiliasi yang berupa anjuran dan tidak mengikat, putusan arbitrase mengikat para pihak. Satu-satunya langkah bagi pihak yang menolak putusan tersebut ialah permohonan Pembatalan ke Mahkamah Agung. Karena adanya kewajiban membayar arbiter, mekanisme arbitrase kurang populer.

3. Pengadilan Hubungan Industrial

Pihak yang menolak anjuran mediator/konsiliator, dapat mengajukan gugatan ke Pengadilan Hubungan Industrial (PHI). Tugas pengadilan ini antara lain mengadili perkara perselisihan hubungan industrial, termasuk mengadili Perselisihan PHK, Perselisihan yang timbul akibat adanya perselisihan hak, perselisihan kepentingan dan perselisihan antar serikat karyawan, serta menerima permohonan dan melakukan eksekusi terhadap Perjanjian Bersama yang dilanggar.

Mekanisme penyelesaian perselisihan hubungan industrial :

a. Tahap pertama dilakukan dengan cara melakukan perundingan Bipartit yang dilakukan oleh kedua belah pihak yaitu pengusaha/pemberi kerja dengan pekerja/buruh atau serikat pekerja/buruh secara musyawarah untuk mencapai mufakat dan harus diselesaikan paling lama 30 hari sejak tanggal dimulainya perundingan. Apabila dalam jangka waktu 30 hari dan salah satu pihak menolak untuk berunding atau telah dilakukan perundingan tetapi tidak mencapai kesepakatan maka perundingan bipartit dianggap gagal. Pernyataan ini sesuai dengan Pasal 3 Ayat (1), (2), dan (3) UU PPHI.

b. Tahap kedua atau langkah selanjutnya yang perlu dilakukan adalah dengan melakukan perundingan Tripartit yaitu melakukan perundingan dengan bantuan pihak ketiga untuk menyelesaikan masalah. Langkah yang diambil adalah salah satu atau kedua belah pihak mencatatkan perselisihannya kepada instansi yang bertanggung jawab di bidang ketenagakerjaan setempat dengan melampirkan bukti 
bahwa upaya-upaya penyelesaian melalui perundingan bipartit telah dilakukan. Sebagaimana disebutkan dalam Pasal 4 Ayat (1) UU PPHI.

c. Apabila bukti-bukti tidak dilampirkan, maka instansi yang bertanggung jawab di bidang ketenagakerjaan mengembalikan berkas untuk dilengkapi paling lambat dalam waktu 7 hari kerja terhitung sejak tanggal diterimanya pengembalian berkas. Setelah menerima pencatatan dari salah satu atau para pihak, instansi yang bertanggung jawab di bidang ketenagakerjaan setempat wajib menawarkan kepada para pihak untuk menyepakati memilih penyelesaian melalui konsiliasi atau melalui arbitrase. Penyelesaian melalui konsiliasi dilakukan untuk penyelesaian perselisihan kepentingan, perselisihan pemutusan hubungan kerja, atau perselisihan antar serikat pekerja/serikat buruh. Sedangkan, penyelesaian melalui arbitrase dilakukan untuk penyelesaian perselisihan kepentingan atau perselisihan antar serikat pekerja/serikat buruh.

d. Jika para pihak tidak menetapkan pilihan penyelesaian melalui konsiliasi atau arbitrase dalam waktu 7 (tujuh) hari kerja, maka instansi yang bertanggung jawab di bidang ketenagakerjaan melimpahkan penyelesaian perselisihan kepada mediator, yaitu pegawai instansi pemerintah yang bertanggung jawab di bidang ketenagakerjaan yang memenuhi syarat-syarat sebagai mediator yang ditetapkan oleh Menteri untuk bertugas melakukan mediasi dan mempunyai kewajiban memberikan anjuran tertulis kepada para pihak yang berselisih untuk menyelesaikan perselisihan hak, perselisihan kepentingan, perselisihan pemutusan hubungan kerja, dan perselisihan antar serikat pekerja/serikat buruh hanya dalam satu perusahaan. Namun, apabila penyelesaian melalui konsiliasi atau mediasi tidak mencapai kesepakatan, maka salah satu pihak dapat mengajukan gugatan kepada Pengadilan Hubungan Industrial. Sebagaimana disebutkan dalam Pasal 5 UU PPHI. Kemudian, pada Pasal 55 UU PPHI disebutkan bahwa Pengadilan Hubungan Industrial merupakan pengadilan khusus yang berada pada lingkungan peradilan umum.

\section{Contoh Kasus}

SH, merupakan seorang pekerja desain di salah satu UD. Printing di kabupaten Bangkalan dia telah bekerja selama hampir satu tahun dengan gaji Rp 1.000.000,00 yang hal ini disepakati saat perekrutan karyawan dan pihak perusahaan mengatakan bahwa gaji 
dengan nominal itu hanya sebagai gaji awal saja dengan berjalan waktu, jika tidak ada masalah dalam pekerjannya maka gaji akan dinaikkan sesuai dengan UMK. Namun, setelah hampir satu tahun menjalankan pekerjaan tersebut dengan baik tanpa masalah, gajinya tetap saja tidak dinaikkan dengan alasan pendapatan perusahaan yang minimal. Akhirnya, ia mengundurkan diri dengan berbagai alasan agar dapat diberhentikan dari UD tersebut.

\section{Penyelesaian}

Dalam kasus yang kita ambil sebagaimana yang telah dipaparkan pada latar belakang diatas, pekerja tersebut gajinya tidak sesuai dengan UMK (Upah Minimum Kabupaten). UMK Bangkalan tahun 2018 ini adalah Rp 1.663.975,00. Sedangkan ukuran pemberian upah atas tenaga kerja telah ditetapkan dalam UU No. 13 Tentang Ketenagakerjaan. Dalam hal ini perusahaan diatas telah melanggar UU No. 13 tentang ketenagakerjaan, sehingga ada sanksi bagi perusahaan tersebut. Namun, apabila perusahaan tidak mampu memberikan upah sesuai UMK, maka disitu ada penangguhan pemberian UMK yang ditujukan langsung ke Gubernur melalui dinas wilayah provinsi.

Apabila terjadi suatu permasalahan seperti buruh/pekerja tidak mendapatkan perlakuan yang wajar, PHK tanpa pesangon, pemberhentian tanpa pemberian pengupahan, maka sistematika penanganan permasalahannya yakni dengan cara melakukan pengaduhan terlebih dahulu, lalu dinas tersebut nantinya bertindak lanjuti dengan cara Bipartit melalui SP (Surat Pekerja) perusahaan. Jika gagal maka melakukan pengaduhan disnaker setempat yang kemudian penindak lanjutan oleh disnaker. Menurut ketentuan Pasal 1 ayat (10) UU No. 2 Tahun 2004 menyatakan bahwa perundingan bipatrit adalah perundingan antara pekerja/buruh atau serikat pekerja/buruh dengan pengusaha untuk menyelesaikan perselisihan hubungan industrial. Bipatrit merupakan langkah pertama untuk menyelesaikan perselisihan hubungan industrial sesuai dengan Pasal 3 ayat (1) UU No.2 Tahun 2004. Tetapi apabila secara bipatrit gagal maka sesuai Pasal 4 ayat (1) UU No.2 Tahun 2004 : "Dalam hal perundingan bipatrit gagal sebagaimana dimaksud dalam Pasal 3 ayat (3), salah satu atau kedua belah pihak mencatatkan perselisihannya kepada instansi yang bertanggung jawab di bidang ketenagakerjaan setempat dengan melampirkan bukti bahwa upaya-upaya penyelesaian melalui perundingan bipatrit telah dilakukan.” 
Penyelesaian perselisihan secara bipatrit tersebut dimaksudkan untuk mencari jalan keluar atas perselisihan hubungan industrial dengan cara musyawarah untuk mencapai kata mufakat secara internal, dalam arti kata tidak melibatkan pihak lain, di luar pihak - pihak yang berselisih. Penyelesaian perselisihan secara bipatrit ini harus diselesaikan paling lama 30 (tiga puluh) hari sejak tanggal dimulainya perundingan. Apabila dalam 30 hari salah satu pihak menolak untuk berunding atau telah dilakukan perundingan tetapi tidak mencapai kesepakatan, perundingan bipatrit dianggap gagal. Tetapi apabila perundingan bipatrit tersebut dapat mencapai kesepakatan penyelesaian, dibuat perjanjian bersama yang ditandatangani oleh para pihak dan mengikat dan menjadi hukum serta wajib dilaksanakan oleh para pihak.

Permasalahan PHK tanpa pemberian pesangon biasanya disebut PHK sepihak yang dilakukan perusahaan. Maka pekerja dapat melakukan pengaduhan ke disnaker, kemudian di mediasi, dan di identifikasi permasalahannya. JIka PHK yang dilakukan oleh perusahaan tersebut karena pekerja melakukan kesalahan/ pelanggaran, telah mendapatkan SP (Surat Pernyataan) melanggar 1, SP 2, SP 3 dan perusahaan melakukan PHK maka secara undang - undang pekerja tersebut tidak mendapat upah pesangon. Misal dalam suatu kasus perusahaan mengalami kebangkrutan dan pekerja belum dibayar selama dua bulan maka yang harus dilakukan yakni dengan menjual peralatan perusahaan yang berharga seperti mesin, computer dan sebagainya. Setelah semuanya terjual maka perusahaan biasanya terlebih dahulu membayar hutang - hutang perusahaan, jika masih ada sisa yaitu untuk membayar gaji karyawan tersebut. Namun apabila setelah menjual semua barang berharga perusahaan dan tidak ada sisanya maka dilakukan perundingan Tripartit. Pada dasarnya, perundingan tripatrit merupakan perundingan yang melibatkan pihak ketiga yang netral. Dalam UU No.2 Tahun 2004 pihak ketiga yang dilibatkan untuk menyelesaikan suatu perselisihan hubungan industrial tersebut adalah mediator, atau kosiliator, atau arbiter. Upaya penyelesaian secara tripatrit ini baru dapat dilakukan apabila usaha tripatrit telah dilakukan. Adapun proses penyelesaian secara tripatrit melalui mediasi, konsiliasi dan arbitrase.

\section{Penyelesaian Melalui Triparit}

Pada dasarnya, perundingan tripatrit merupakan perundingan yang melibatkan pihak ketiga yang netral. Dalam UU No.2 Tahun 2004 pihak ketiga yang dilibatkan untuk 
menyelesaikan suatu perselisihan hubungan industrial tersebut adalah mediator, atau kosiliator, atau arbiter. Upaya penyelesaian secara tripatrit ini baru dapat dilakukan apapbilaa usaha tripatrit telah dilakukan. Adapun proses penyelesaian secara tripatrit melalui mediasi, konsiliasi dan arbitrase sebagaimana diuraikan secara lebih terperinci dibawah.

\section{Penyelesaian Melalui Mediasi}

Mediasi ialah penyelesaian perselisihan hak, perselisihan kepentingan, perselisihan PHK, dan perselisihan antar serikat pekerja atau serikat buruh hanya dalam satu perusahaan, melalui musyawarah yang ditengahi oleh seorang mediator yang netral, sebagaimana tercantum dalam pasal 1 angka 1 UUPPHI). Pada dasarnya, penyelesaian melalui mediasi mempunyai karakteristik yang bersifat unggulan sebagai berikut (Mulyadi. L, 2011) :

1. Voluntary

Keputusan untuk bermediasi diserahkan kepada kesepakatan para pihak sehingga dapat diciptakan suatu putusan yang merupakan kehendak dari para pihak. Karena dikehendaki para pihak, putusan yang dihasilkan bersidat win-win solution.

2. Informal dan Fleksibel

Bila diperintahkan, para pihak sendiri dengan bantuan mediator dapat mendesain sendiri prosedur, tata cara, prosedur maupun mekanisme sangat berbeda jauh antara litigasi dengan mediasi.

\section{Interested based}

Di dalam mediasi tidak dicari siapa yang salah atau siapa yang benar, tetapi yang lebih diu tamakan adalah bagaimana mediasi tersebut menghasilkan dan mencapai kepentingan masing-masing pihak.

\section{Future Looking}

Karena hakikat mediasi lebih menjaga kepentingan masing-masing pihak, sehingga lebih menekankan untuk menjaga hubungan para pihak yang bersengketa ke depan dan tidak berorientasi ke masa lalu.

5. Parties oriented

Orientasi mediasi yang bersifat prosedur yang informal, para pihak lebih aktif berperan dalam proses mediasi tanpa tergantung pada peran pengacara. 


\section{Parties control}

Mediator tidak dapat memaksakan kehendak atau pendapatnya untuk mencapai kesepakatan karena penyelesaian sengketa melalui mediasi merupakan keputusan dari pihak-pihak itu sendiri.

Pemerintah dapat mengangkat seorang Mediator yang bertugas melakukan Mediasi atau Juru Damai yang dapat menjadi penengah dalam menyelesaikan sengketa antara Buruh dan Majikan. Seorang Mediator yang diangkat tersebut mempunyai syarat-syarat sebagaimana dituangkan dalam Pasal 9 Undang-undang No.2 Tahun 2004. Pengangkatan dan akomodasi mediator ditetapkan oleh Menteri Tenaga Kerja. Bila telah tercapai kesepakatan penyelesaian perselisihan melalui Mediator tersebut dibuatkan "perjanjian bersama" yang ditandatangani para pihak dan mediator tersebut, kemudian perjanjian tersebut didaftarkan di Pengadilan Hubungan Industrial pada Pengadilan Negeri setempat. Tetapi apabila tidak tidak terjadi kesepakatan antara pihak bersengketa maka dapat dilakukan mediasi. Mediasi dapat dikatakan sebagai salah satu upaya dari pihak yang dapat dilakukan oleh para pihak, sebelum sampai ke pengadilan. Penyelesaian masalah di tahap mediasi sangat cepat tidak lebih dari 30 hari kerja, dan mediator wajib untuk memulai sidang mediasi selambat-lambatnya 7 hari sejak dilimpahkan (pasal 10 dan 15 UUPHI).

\section{Penyelesaian Melalui Konsiliasi}

Penyelesaian melalui Konsiliator yaitu pejabat Konsiliasi yang diangkat dan diberhentikan oleh Menteri Tenaga Kerja berdasarkan saran organisasi serikat pekerja atau Serikat Buruh. Segala persyaratan menjadi pejabat Konsiliator tersebut didalam pasal 19 Undang-Undang No.2 Tahun 2004. Dimana tugas terpenting dari Kosiliator adalah memangil para saksi atau para pihak terkait dalam tempo selambat - lambatnya 7 (tujuh) hari sejak menerima penyelesaian Konsiliator tersebut. Pejabat Konsiliator dapat memanggil para pihak yang bersengketa dan membuat perjanjian bersama apabila kesepakatan telah tercapai. Pendaftaran perjanjian bersama yang diprakarsai oleh Konsiliator tersebut dapat didaftarkan didepan pengadilan Negeri setempat. Demikian juga eksekusinya dapat dijalankan di Kepaniteraan Pengadilan Negeri setempat tesebut.

\section{Penyelesaian Melalui Arbitrase}


Penyelesaian perselisihan melalui arbitrase pada umumnya, telah diatur di dalam Undang - undang Nomor 30 Tahun 1999 tentang Arbitrase dan Alternatif Penyelesaian Sengketa yang berlaku di bidang sengketa perdagangan. Oleh karena itu arbitrase hubungan industrial yang diatur dalam undangundang ini merupakan pengaturan khusus bagi penyelesaian sengketa di bidang hubungan industrial. Undang-undang dapat menyelesaikan perselisihan melalui arbitrase meliputi perselisihan kepentingan dan perselisihan antar Serikat Pekerja dan Majikan didalam suatu perusahaan. Untuk ditetapkan sebagai seorang Arbiter sebagaimana yang dimaksud dalam Pasal 31 ayat (1). Para pihak yang bersengketa dapat memilih Arbiter yang mereka sukai seperti yang ditetapkan oleh Menteri Tenaga Kerja. Putusan Arbiter yang menimbulkan keraguan dapat dimajukan tuntutan ingkar kepada Pengadilan Negeri setempat dengan mencantumkan alasan-alasan otentik yang menimbulkan keraguan tersebut. Putusan Pengadilan Negeri dalam Pasal 38 Undang-undang No.2 Tahun 2004, dapat membuat putusan mengenai alasan ingkar dan dimana tidak dapat diajukan perlawanan lagi. Bila tercapai perdamaian, maka menurut isi Pasal 44 Undang-undang No.2 Tahun 2004, seorang arbiter harus membuat Akte Perdamaian yang ditandatangani oleh kedua belah pihak dengan disaksikan seorang Arbiter atau Majelis Arbiter.

\section{Pengaruh Dan Peran Pimpinan Terhadap Keharmonisan Hubungan Industrial Di UD. CSC Klampis}

UD. CSC sendiri merupakan suatu bentuk usaha dagang yang berada di daerah klampis, memiliki banyak karyawan tentunyan tidak mudah dalam mempertahankan harmonisasi hubungan industrial demi terjalinnya mitra kerja yang baik disamping dari hal itu tentunya tidak akan lepas dari sebuah perselisihan hubungan antar karyawan maupun dengan perusahaan sendiri, masalah yang timbul seringkali antara perusahaan dan karyawan ialah kedisiplinan karyawan yang seringkali sangat butuh perhatian dan pembinaan, pembinaan sendiri dilakukan dengan cara breaving ataupun perundingan internal antara karyawan yang bersangkutan dengan petinggi usaha selain daripada itu pihak pimpinan memberikan contoh sikaptersendiri untuk memotivasi karyawan agar lebih disiplin sedangkan masalah sesama karyawan ialah kecemburuan social, perusahaan memiliki tingkat solidaritas yang tinggi terhadap karyawan demi terjalin hubungan 
industrial yang baik dalam contoh nyata ialah pemberian kompensasi terhadap karyawan yang mempunyai produktifitas yang tinggi.

Adanya kompetensi karyawan merupakan hal yang penting demi berkembangnya usaha dan produktifitas kerja bagi karyawan, dalam upaya meningkatkan kompetensi para karyawannya UD. CSC melakukan suatu pembinaan atas peningkatan kompetensi karyawan seperti, training, kursus dan diikutkan dalam seminar.

Efektifitas mediasi dalam menyelesaikan perselisihan hubungan industrial tidak terlepas dari faktor pendorong dan penghambatnya. Faktor pendorong efektifitas mediasi dalam penyelesaian perselisihan hubungan industrial adalah adanya itikad baik dari para pihak. Selain mediator membantu para pihak agar keluar dari persengketaannya, para pihak juga harus mempunyai itikad baik dengan kesungguhan hati mengupayakan perdamaian dengan tidak bermaksud untuk memperoleh keuntungan yang lebih besar.5 untuk menyelesaikan perselisihan mereka dengan perdamaian, para pihak mau menerima saran atau anjuran dari mediator karena saran atau anjuran itu bertujuan untuk mendamaikan para pihak sehingga mencapai kata sepakat, faktor lain juga adalah mediator yang bersifat netral dan tidak memihak kepada salah satu pihak dan keberhasilan mediasi juga tidak terlepas dari pengetahuan yang luas tentang hukum ketenagakerjaan yang dimiliki oleh mediator serta keterampilan dalam mediasi. Faktor - faktor tersebutlah yang mendorong efektivitas mediasi sebagai penyelesaian perselisihan hubungan industrial. Selain faktor pendorong, ada juga faktor penghambat. Faktor penghambat efektivitas mediasi dalam menyelesaian perselisihan hubungan industrial adalah para pihak yang masih emosi, kuasa hukum yang menghambat proses mediasi karena ada beberapa kuasa hukum yang lebih memilih memenangkan perkara dipengadilan. Dan ketidak hadiran salah satu pihak dalam proses mediasi hubungan industrial juga dapat menjadi penghambat proses mediasi sehingga penyelesaian perselisihan hubungan industrial melalui mediasi menjadi tidak efektif.

\section{KESIMPULAN DAN SARAN}

Peraturan undang-undang ketenagakerjaan merupakan bentuk campur tangan pemerintah dalam hubungan industrial yang bertujuan untuk menjamin hak - hak dasar pekerja/buruh dan meniamin kesamaan kesempatan serta perlakuan tanpa diskriminasi atas dasar apapun untuk mewujudkan kesejahteraan pekerja/buruh dan keluarganva dengan 
tetap memperhatikan perkembangan kemajuan dunia usaha. Menurut hukum ketenagakerjaan, Bipartit dan Tripartit sering disebut dengan perundingan Bipartit dan Perundingan Tripartit. Keduanya bertujuan untuk menyelesaikan perselisihan hubungan kerja atau hubungan industrial antara pengusaha/perusahaan/pemberi kerja dengan pekerja/buruh. Sebagaimana disebutkan dalam Pasal 1 Angka 10 Undang-undang Nomor 2 Tahun 2004 tentang Penyelesaian Perselisihan Hubungan Industrial yang selanjutnya disebut UU PPHI menyebutkan bahwa perundingan bipartit adalah perundingan antara pekerja/buruh atau serikat pekerja/serikat buruh dengan pengusaha untuk menyelesaikan perselisihan hubungan industrial. Sedangkan, perundingan Tripartit adalah penyelesaian perselisihan hubungan industrial melalui pihak ketiga.

\section{DAFTAR PUSTAKA}

Asyhadie Zaeni.2015. Hukum Kerja: Hukum Ketenagakerjaan Bidang Hubungan Kerja. Jakarta:PT. Raja Grafindo Persada.

Khakim Abdul. 2010. Aspek Hukum Penyelesaian Perselisihan Hubungan Industrial (Antara Peraturan dan Pelaksanaan). Bandung: PT. Aditya Bakti.

Suwantono, Priansa Donni Juni. 2011. Manajemen SDM dalam Organisasi Publik dan Bisnis. Bandung: Alfabeta.

Undang-Undang Republik Indonesia No.13 Tahun 2003 Tentang ketenagakerjaan. Undang-Undang Republik Indonesia No. 2 Tahun 2004 Penyelesaian Perselisihan Hubungan Industrial. 